UDC 57.087

\author{
Y. Udovychenko ${ }^{1}$, A. Popov ${ }^{1}$, Ph.D., I. Chaikovsky ${ }^{2}$ \\ ${ }^{1}$ National Technical University of Ukraine «Kyiv Polytechnic Institute», \\ off.423, Politekhnichna Str., 16, Kyiv, 03056, Ukraine. \\ ${ }^{2}$ Glushkov Institute of Cybernetics of NAS of Ukraine, \\ Glushkov ave. 40, Kiev, Ukraine.
}

\title{
Effective Surface Area of Current Density Distribution Maps
}

Magnetocardiography (MCG) is a technique of measuring the weak magnetic fields generated in the heart during its functioning. MCG can be measured using a superconducting quantum interference device (SQUID) sensor that converts magnetic flux to voltage, and is the most sensitive sensor to detect magnetism. In this paper, analysis of myocardium current density distribution maps is proposed. Effective surface area dependence on time for full and divided into 4 parts current density distribution maps is obtained. Ref. 6, figs. 4.

Keywords: magnetocardiography, current density imaging, effective surface area, current density distribution map.

\section{Introduction}

Magnetocardiography is one of the most progressive tools for diagnosis and investigation of heart diseases, such as coronary heart disease. Noninvasiveness, contactlessness, high sensitivity makes magnetocardiography suitable for this purpose and comfortable in use for physician [1]. MCG analysis is used for diagnosis of ischemic heart disease by comparing magnetic field maps for both normal subjects and patients with ischemic heart disease [2]. Cardiac-current images that include morphological information on the heart may be obtained by projecting a twodimensional (2-D) current-arrow map (CAM), which is calculated from magnetocardiogram signals, onto a three-dimensional (3-D) standard heart model, which is intended to be applicable to all adult subjects [3]. The noninvasive magnetocardiographic mapping data is used for diagnostics and analysis of Wolf-Parkinson-White syndrome [4] and other diseases accompanied by lesions of current flow in the heart muscles.

One of the approaches of studying magnetic field in human heart is analysis of current density distribution maps (CDDM). Current density imaging is a noninvasive measurement of the electrical current density inside a conductive sample. Current density imaging measures the local magnetic field vector generated by the current flowing inside the tissue and uses a vector curl operation to calculate the current density. Since current density imaging can be performed contactlessly using SQUID, it is inherently noninvasive (when compared with multiple-electrode measurements) and does not suffer from the limitations of aforementioned techniques. Furthermore, current flow information can be calculated from the current density data using streamline analysis [7]. Aim of the study is analysis of CDDM surface area dependence on time and current density threshold for further determination of diagnostically useful characteristics.

\section{Surface area dependence for CDDM}

In this study analysis of CDDM effective surface area dependence on time was made. The technique used here is presented in the work [6]. The area of CDDM may be found as

$$
S_{\Sigma}=N_{x} \cdot N_{y}
$$

. After that the threshold $\lambda(\%)$ for current density, which is represented by brightness on CDDM, is specified. Then the threshold current density is calculated

$$
i_{\lambda}(t)=i_{\max }(t) \cdot \lambda
$$

After that threshold processing of a map $I\left(t, n_{x}, n_{y}\right)$ is performed

$$
I_{\lambda}\left(t, n_{x}, n_{y}\right)= \begin{cases}I\left(t, n_{x}, n_{y}\right), & I\left(t, n_{x}, n_{y}\right)>i_{\lambda}, \\ 0, & I\left(t, n_{x}, n_{y}\right) \leq i_{\lambda} .\end{cases}
$$

where $I\left(t, n_{x}, n_{y}\right)$ - current density in particular point of CDDM at defined moment.

Then effective surface area can be found by the formula

$$
S_{\lambda}(t)=\frac{N_{\lambda}(t)}{S_{\Sigma}} \cdot 100 \%
$$

Thus each CDDM (Fig.1) in this study is formed by using and transformation of current density vec- 
tors, obtained using MCG. Each CDDM is a grayscale discrete image with size of $M \times N$ pixels, where white color corresponds the highest brightness and black responds the least brightness. Thus brightness of an image corresponds to the current density value in corresponding point. CDDMs are built for definite moments of time with some step (up to $10 \mathrm{~ms}$ ) during $T$ wave of electrocardiogram $Q T$ interval. It gives possibility to associate ECG data with corresponding dependences, calculated from CDDMs.

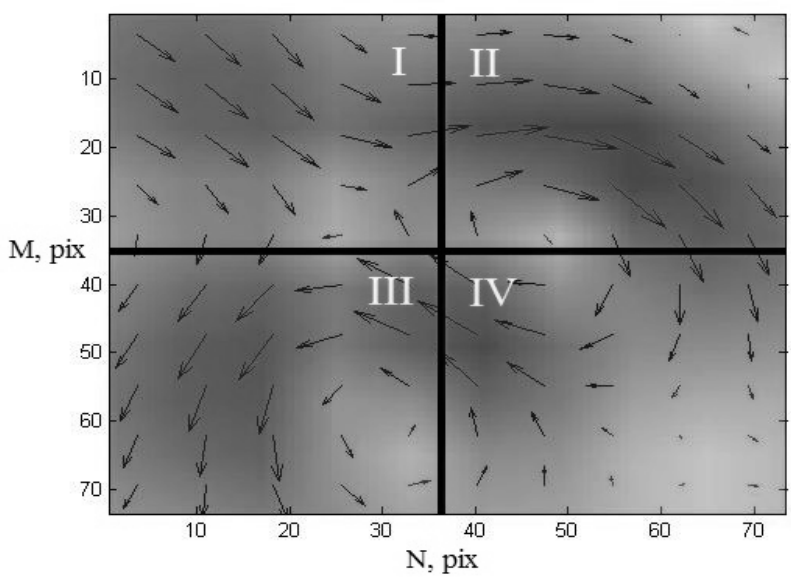

Fig. 1. Current density distribution map

For the present study 340 CDDMs of a group of patients with similar diagnosis were used. The main purpose was finding similarities among CDDMs of this group. Effective surface area was calculated for each map, using equations from our previous study [6] with threshold of $30 \%$ of highest current density value in a full CDDMs set for all patients in studied group.

Time dependence of effective surface area for the studied group of patients is shown in Figure 2 in boxplot view. It can be observed that the values of effective surface area for each time instant differ from one CDDM to another. For time intervals 0 $0,132 \mathrm{~ms}$ and $0,324-0,396 \mathrm{~ms}$, value of effective surface area is almost zero. Values of effective surface area in the interval of $0,144-0,310$ ms have large scatter, except time instants of 0,24 and $0,264 \mathrm{~ms}$. But two values isn't enough for definite decision about CDDMs set of new patient belonging to the studied group.

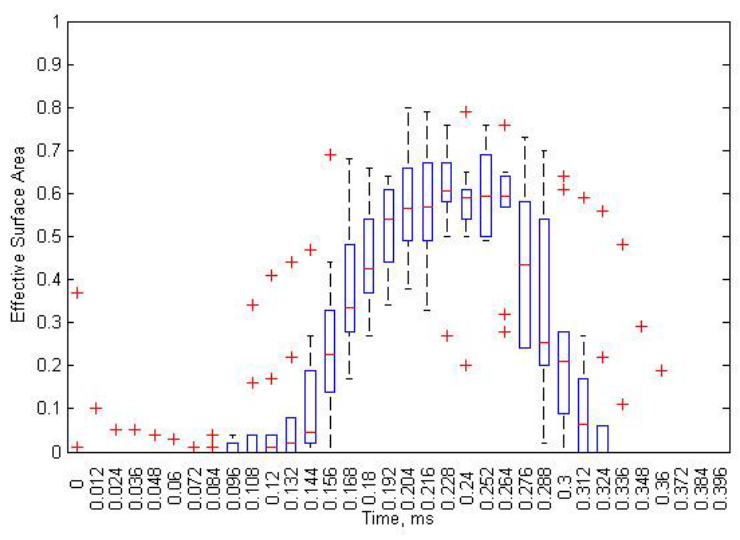

Fig. 2. Effective surface area dependence on time for a group of patients

A new approach to assist this definition is proposed in this paper. This is dividing each CDDM into several parts. In this study, each CDDM was divided into 4 equal parts (quarters), as shown in Figure 1. Then each quarter of CDDM in CDDMs set was processed in the same way, as full CDDM has been: for each quarter the effective surface area (Figure 3) was found. Figure 4 shows the effective surface area dependence on time for each quarter of each sub-CDDM in CDDMs set of studied group of patients. From results obtained during this work it can be seen that for finding the similarities among CDDMs set for studied group and further definition of new patient's belonging to this group, informative is time interval $0,096-0,324$ ms.

First quarters of each map have large effective surface area value scattering, so first quarter isn't useful for our purposes. Effective surface area has similar values at time intervals $0,18-0,204 \mathrm{~ms}$ for the second quarter, $0,168-0,192$ for the third quarter and $0,204-0,228 \mathrm{~ms}$ for the fourth quarter. 

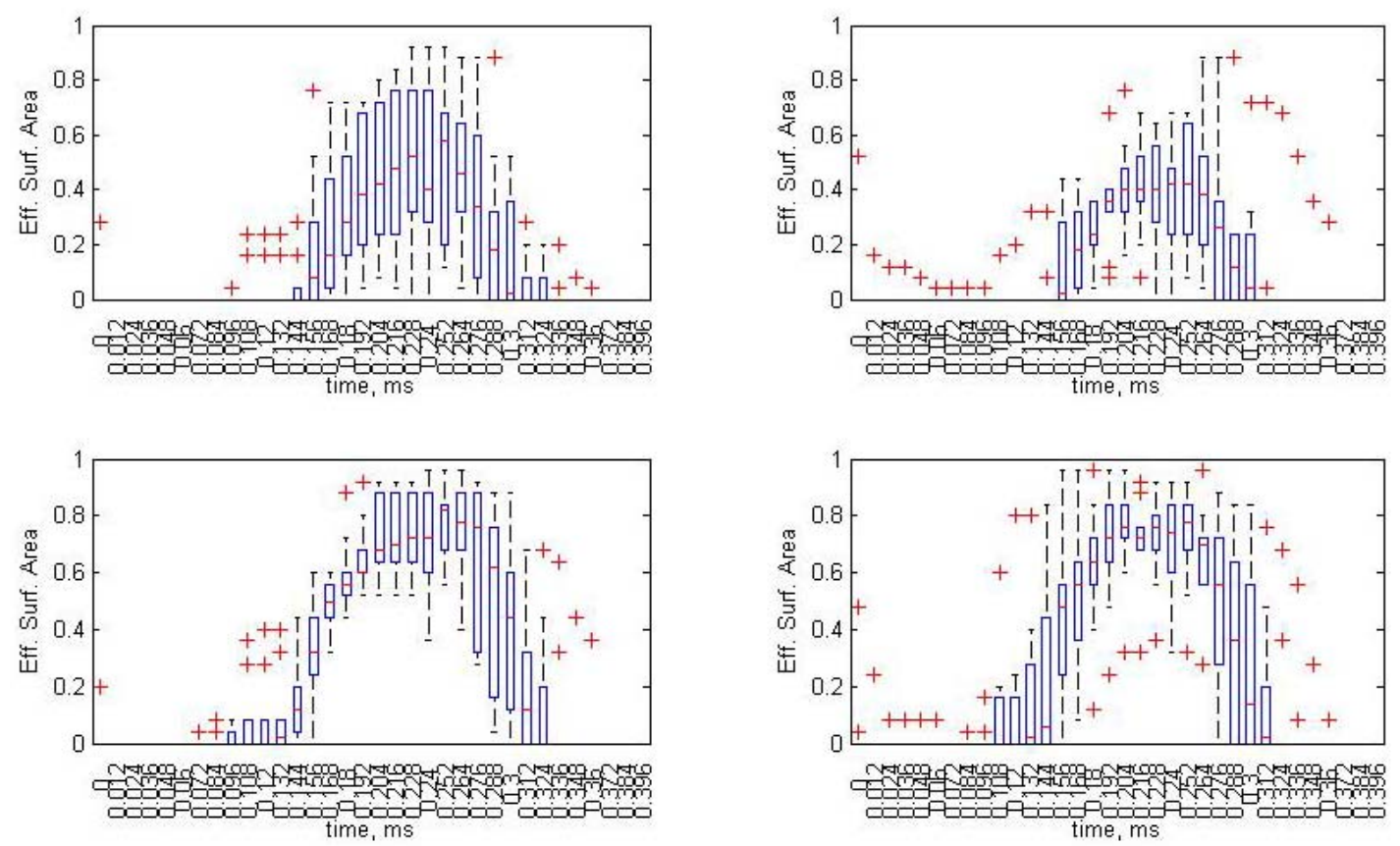

Fig. 3. Effective surface area of each submap dependence on time for a group of patients

Thus, application of such approach to CDDM processing provides increasing the amount of time instants in which values of effective surface area is informative for finding the similarities among
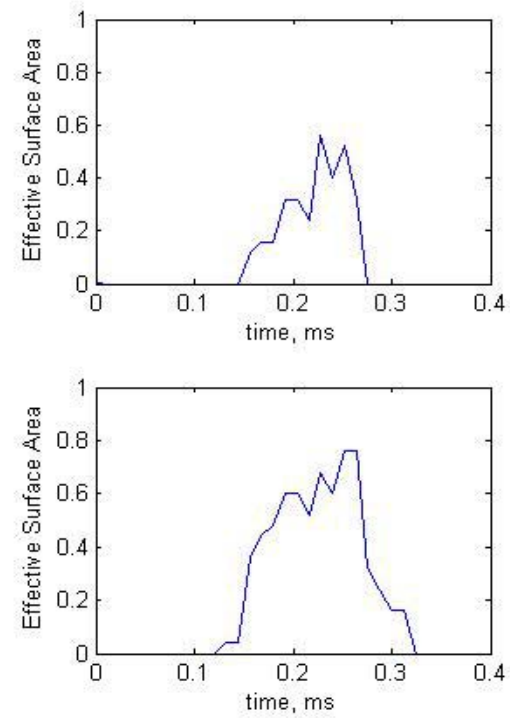

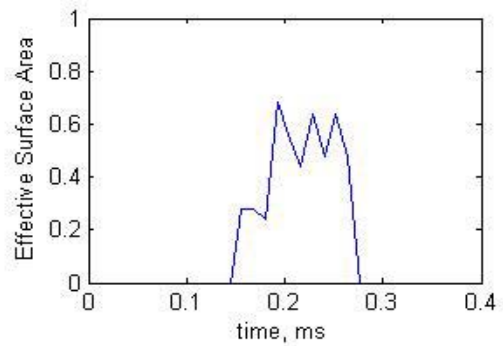

CDDMs set and further definition of new patient's belonging to the particular group, to time interval $0,18-0,228 \mathrm{~ms}$.

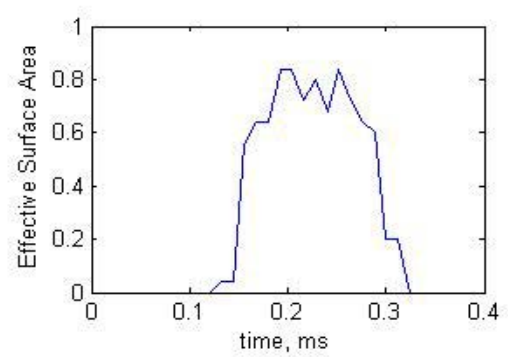

Fig. 4. Effective surface area of each submap dependence on time for one patient

\section{Conclusions}

The technique of studying of CDDM surface area dependence on time is proposed and tested for 340 current density distribution maps, both full and divided into 4 parts, showing the time instants in which effective surface area values have the smallest scatter. The proposed approach can be used for finding the similarities among CDDMs set for studied group and further definition of new patient's belonging to this group. 


\section{References}

1. Chaikovsky I. et al. (2011), "Magnetocardiography in clinical practice: algorithms and technologies for data analysis" in Medical Science 3-4, June 2011, pp. 21-38.

2. Tsukada K. et al. (2000), "Magnetocardiographic mapping characteristic for diagnosis of ischemic heart disease" in Computers in Cardiology 2000, Cambridge, MA, Sept. 2000, pp. 505-508.

3. Ogata K. et al. (2003), "Projecting cardiaccurrent images onto a 3-D standard heart model" in Engineering in Medicine and Biology Society, 2003, Vol. 1, Sept. 2003, pp. 517-520.

4. Geselowitz, David B. (2003), "Magnetocardiography: an overview" in IEEE Transaction on Biomedical Engineering, Vol. BME-26, Sept. 979, pp. 497-504.
5. Richard S. et al. (2003), "Measurement of thoracic current flow in pigs for the study of defibrillation and cardioversion," IEEE Transactions on Biomedical Engineering, Vol. 50, Oct. 2003 pp. 1167-1173.

6. Udovychenko Y., Popov A., Chaikovsky I. (2014), "Current Density Distribution Maps Threshold Processing" in 2014 IEEE 34 ${ }^{\text {th }}$ International Scientific Conference on Electronics and Nanotechnology (ELNANO), Apr. 2014, pp. $313-315$.

Поступила в редакцию 20 сентября 2014 г.

УДК 57.087

\author{
Є.А. Удовиченко ${ }^{1}$, А.О. Попов ${ }^{1}$, канд.тех.наук, І.А. Чайковський ${ }^{2}$ \\ ${ }^{1}$ Національний технічний університет України «Київський політехнічний інститут», \\ вул. Політехнічна, 16, 03056, Київ, Україна. \\ ${ }^{2}$ Інститут кібернетики імені В. М. Глушкова НАН України, просп. Академіка Глушкова, \\ 40, Київ, Україна.
}

\title{
Ефективна площа поверхні карт розподілу щільності струму
}

Магнітокардіографія (МКГ) є методикою вимірювання слабких магнітних полів, які виникають в серці під час його функціонування. МКГ може бути виміряна за допомогою надпровідних квантових інтерфреренційних датчиків (СКВІД), які перетворюють магнітний потік в напругу, $і \epsilon$ найбільш чутливими датчиками для виявлення магнетизму. У даній роботі пропонується аналіз карт розподілу щільності струму міокарда. Одержано залежність ефективної площі поверхні від часу для цілих і розділених на 4 частини карт розподілу щільності струму. Бібл. 6, рис. 4.

Ключові слова: Магнітокардіографія, відображення щільності струму, ефективна площа поверхні, карта розподілу щільності струму.

\section{УДК 57.087}

\section{Е.А. Удовиченко ${ }^{1}$, А.А. Попов ${ }^{1}$, канд.тех.наук, И.А. Чайковський ${ }^{2}$}

${ }^{1}$ Национальный технический университет Украины «Киевский политехнический институт», ул. Политехническая, 16, 03056, Киев, Украина.

${ }^{2}$ Інститут кібернетики імені В. М. Глушкова НАН України, просп. Академика Глушкова. 40, Киев, Украина.

\section{Эффективная площадь поверхности карт распределения плотности тока}

Магнитокардиография (МКГ) является методикой измерения слабых магнитных полей, создаваемых в сердце во время его функционирования. МКГ может быть измерена с помощью сверхпроводящих квантовых интерференционных датчиков (СКВИД), которые преобразуют магнитный поток в напряжение, и являются наиболее чувствительными датчиками для обнаружения магнетизма. В данной работе предлагается анализ карт распределения плотности 
тока миокарда. Получена зависимость эфффективной площадь поверхности от время для целых и разделенных на 4 части карт распределения плотности тока. Библ. 6, рис. 4.

Ключевые слова: Магнитокардиография; отображение плотности тока, эфффективная площадь поверхности, карта распределения плотности тока.

\section{Список использованных источников}

1. Chaikovsky I. et al., "Magnetocardiography in clinical practice: algorithms and technologies for data analysis" in Medical Science 3-4, June 2011, pp. 21-38.

2. Tsukada K. et al., "Magnetocardiographic mapping characteristic for diagnosis of ischemic heart disease" in Computers in Cardiology 2000, Cambridge, MA, Sept. 2000, pp. 505-508.

3. Ogata K. et al., "Projecting cardiac-current images onto a 3-D standard heart model" in Engineering in Medicine and Biology Society, 2003, Vol. 1, Sept. 2003, pp. 517-520.

4. Geselowitz, David B., "Magnetocardiography: an overview" in IEEE Transaction on Biomedical Engineering, Vol. BME-26, Sept. 979, pp. 497-504.

5. Richard S. et al., "Measurement of thoracic current flow in pigs for the study of defibrillation and cardioversion," IEEE Transactions on Biomedical Engineering, Vol. 50, Oct. 2003 pp. 1167-1173.

6. Udovychenko Y., Popov A., Chaikovsky I., "Current Density Distribution Maps Threshold Processing" in 2014 IEEE 34 ${ }^{\text {th }}$ International Scientific Conference on Electronics and Nanotechnology (ELNANO), Apr. 2014, pp. $313-315$.

(c) Udovychenko Y., Popov A., Chaikovsky I., 2014 